\title{
Pragmatist Aesthetics: Histories, Questions, and
} Consequences

An Interview with Richard Shusterman

\section{Richard Shusterman and Roberta Dreon}

\section{(2) OpenEdition}

\section{Journals}

Electronic version

URL: http://journals.openedition.org/ejpap/2261

DOI: 10.4000/ejpap.2261

ISSN: 2036-4091

\section{Publisher}

Associazione Pragma

\section{Electronic reference}

Richard Shusterman and Roberta Dreon, "Pragmatist Aesthetics: Histories, Questions, and Consequences", European Journal of Pragmatism and American Philosophy [Online], XIII-1 | 2021, Online since 02 April 2021, connection on 04 April 2021. URL: http://journals.openedition.org/ejpap/2261 ; DOI: https://doi.org/10.4000/ejpap.2261

This text was automatically generated on 4 April 2021.

\section{(c) (i) (9)}

Author retains copyright and grants the European Journal of Pragmatism and American Philosophy right of first publication with the work simultaneously licensed under a Creative Commons AttributionNonCommercial-NoDerivatives 4.0 International License. 


\title{
Pragmatist Aesthetics: Histories, Questions, and Consequences
}

\author{
An Interview with Richard Shusterman
}

Richard Shusterman and Roberta Dreon

\begin{abstract}
Roberta DREON - Richard Shusterman is one of the leading figures in the current field of pragmatist aesthetics and he has undoubtedly played a pivotal role in recovering a pragmatist approach to aesthetics. His book Pragmatist Aesthetics was simultaneously published in France under the title L'Art à l'état vif. La pensée pragmatiste et l'esthétique populaire in 1992, paving the way for a long awaited French translation of Dewey's Art as Experience (Dewey 1989) in 2010 (Dewey 2005/2010), beautifully edited by Jean-Pierre Cometti. Shusterman's work further developed into an explicit claim in favor of philosophy as a way of life and finally led to somaesthetics, an original proposal within the contemporary debate, producing a strongly practical turn in the embodied trend within contemporary philosophy.

In reconstructing your development of a pragmatist approach to aesthetics, you state that your first reading of Dewey's 1934 volume was not decisive. Rather, you emphasize the importance of Richard Rorty's and Joseph Margolis's departures from analytic philosophy, which led you to consider continental philosophy a resource and to find a plausible alternative for developing a non-foundational approach in philosophy "under the banner of a renewed pragmatism" (Shusterman 2014: 23). What, if any, are the advantages of pragmatist aesthetics as a third way between the analytic philosophy of art and continental aesthetics - notwithstanding the fact that it is a huge field in itself with different, sometimes even conflicting positions?
\end{abstract}

Richard SHUSTERMAN - Since you mention the late Jean-Pierre Cometti in passing, let me pause for a moment to emphasize how important he was for the reception of pragmatism in France. His contribution went far beyond his French translation of Dewey's Art as Experience, for which he engaged a number of good translators to help him complete the job. He even enlisted me to write the preface to this French edition (Shusterman 2005/2010). To be precise, this French edition was first published in 2005 by Éditions Farrago together with the University of Pau Press, but was later republished by Gallimard. However, before translating Dewey's aesthetics, JeanPierre Cometti had already translated works of neopragmatists: Rorty, Putnam, Goodman, and me. He also wrote an excellent book on pragmatism for Gallimard, 
which had an impressive chapter on pragmatist aesthetics that included an insightful discussion of somaesthetics (Cometti 2010).

Today it is hard to imagine how difficult it was in the 1990s to find a French publisher willing to publish Dewey's aesthetic masterpiece. When I first came to Paris in 1990, invited by Pierre Bourdieu, I tried to convince him to publish Art as Experience in his collection with Minuit. He said it was out of the question because Dewey's tastes in art were far too old fashioned for Parisian intellectual tastes, and that they were even too old-fashioned when Dewey published the book in 1934. I also tried to convince Gerard Genette, the influential literary theorist who had a book series with Le Seuil and had successfully published some of Arthur Danto's books in aesthetics. If Bourdieu rejected Art as Experience as demodé, Genette regarded it as too longwinded (his expression was trop bavard). Frustrated by the failure to find a French publisher for Dewey's aesthetics, I had the consolation that the Dewey-inspired book I was then writing on pragmatist aesthetics was contemporary enough (with its study of rap) to interest Jerome Lindon of Minuit, who eventually published it in January 1992. However, Lindon insisted on removing three of my book's more technical chapters (on interpretation and ontology), which he thought were too narrowly specialized and demanding to interest a sufficient number of French readers. He also insisted that pragmatism not figure in the book's title, which came to be L'Art à l'état vif. I trusted his publishing experience and the book proved popular enough to reach a wide audience, even the TV audience of M-6's Rapline, which interviewed me about the book. It was only after the publication of L'Art à l'état vif that I met Jean-Pierre Cometti and, later, other French philosophers interested in American philosophy.

Since we are doing this interview for the European Journal of Pragmatism and American Philosophy, I take this opportunity to express my respect for the French pragmatists. It has been my privilege to work closely with them, not only on philosophical projects but also on artistic ones. Through them, I had the opportunity of doing pragmatist aesthetics in practice by curating an art show in Paris (Shusterman 2012a). I could also share with them my experimental work in performance art, much of which took place in and around Paris. Those aesthetic experiences of performance prompted me to write a bilingual philosophical novella, The Adventures of the Man in Gold/Les Aventures de l'homme en or - illustrated with images from those performances and published in Paris (Shusterman 2016a) - as another experiment in pragmatist aesthetics. This hybrid, illustrated book constitutes an experiment in trying to find new ways (verbal and nonverbal) of communicating philosophical ideas I regard as central to aesthetics, to somaesthetics, and to the pragmatist idea of philosophy as an embodied art of living. (of course, philosophers like Diderot and Voltaire were already philosophizing through fiction in the eighteenth century, so I make no claim to novelty; and I'd like to believe that Paris remains a place in our conservative world where there remains a spirit of intellectual experimentation.) In any case, I regard such experiments in artistic practice and aesthetic experience as central to my work in pragmatism. One might characterize these performative and literary experiments as belonging to a "poetic pragmatism," though I know that some colleagues reject them as far beyond the borders of philosophy. My own understanding of the spirit of pragmatist experimentalism involves a probing or testing the borders of academic philosophy, with sincere respect for academic discipline but without slavish conformism to all its standard conventions and territorial boundaries. 
This point leads me back, finally, to your initial question about the academic fields of analytic, continental, and pragmatist philosophy. It was long ago, back in the late 1980s and early 1990s, when I proposed pragmatist aesthetics as a third way that avoids the aridness of analytic aesthetics and the excesses and obscurity of some fashionable continental theory at that time. My purpose was clearly partisan or political: to create greater recognition, in the Anglo-American philosophical field, of the value of pragmatism for aesthetics and the philosophy of art, particularly for the value of Dewey's aesthetics, which analytic aesthetics had dismissed and continental theory largely ignored. Today, I would not advocate for pragmatism precisely in that way, although I remain convinced that classical and contemporary pragmatists have many useful things to say about aesthetics. The current philosophical field is not the same; analytic aesthetics and continental theory are not what they were in 1990 when I pleaded for pragmatist aesthetics. By now pragmatism has also won a secure place in aesthetics and needs no special pleading. In addition, pragmatist aesthetics today is a broad field with multiple and diverse voices, so it is difficult to generalize about pragmatist aesthetics as if it had a defining essence.

There is still another danger in reifying the notion of pragmatist aesthetics as if it were a well-defined movement or school that is competing with rival schools. This danger is sectarianism, which I think can encourage conformism and impair the freedom of thought that I believe is important for philosophical thinking. I acknowledge that identifying one's thought with a philosophical school or tradition is a natural and perhaps necessary response to deep psychological and professional needs. It is practically impossible to find a job in philosophy these days without declaring one's allegiance to one philosophical school or another. I am very grateful that there is a journal like EJPAP, which is hosting this interview and which serves the interests of philosophers like myself who identify with the pragmatist tradition. However, today I would refrain from explicitly pitting pragmatist aesthetics against other approaches; indeed my own work has always sought to incorporate thinkers outside the pragmatist field (including analytic and continental philosophy). Let me conclude this response by invoking the undisputed source of pragmatist aesthetics, John Dewey, who (for good reasons, as I've often noted), not only never used the term "pragmatism" in Art of Experience but even explicitly (and repeatedly) rejected the notion of pragmatist aesthetics after its publication (Shusterman 2014).

\begin{abstract}
米
Roberta DREON - As you often state, Dewey's aesthetics was deeply rooted in his conception of experience. His view of experience rejected subjectivist, dualistic, and atomistic conceptions of experience, including the empiricist one (Dewey 1980 and James 1976), and rested on a strongly naturalistic foundation which he originally derived from Darwin. Famously, this aspect of Dewey's reflection was rejected by Rorty, who saw a metaphysical residue in it that should be abandoned in a post-dogmatic, non-foundational approach to philosophy. Do the naturalistic, albeit not reductive, roots of Dewey's aesthetics still play a role in your pragmatist aesthetics, even though you have never worked out an explicit theory of experience? And, if so, does your own proposal fall within Rorty's objection?

Richard SHUSTERMAN - Yes, my philosophical stance is naturalistic, not only in aesthetics and somaesthetics, but also in philosophy of mind and culture. In Pragmatist Aesthetics, I defended Dewey's aesthetic naturalism, while in Body
\end{abstract}


Consciousness (Shusterman 2008), I defend and elaborate on Dewey's naturalist, emergent account of mind. I also share a naturalistic view of culture as both emerging from nature and reciprocally shaping nature, including human nature, even in its physical dimensions (Shusterman 2002). However, I don't understand why having a naturalistic stance requires formulating a systematic or explicit theory of experience as Dewey did. Rorty's naturalism comes with a radical repudiation of experience as something we should not theorize about but rather should exclude altogether from our philosophical thinking. I think this total exclusion is misguided, even if I believe that some of Dewey's uses of experience are questionable. One of the things I deeply appreciate in Dewey's account of experience is the need to recognize our human weakness and vulnerability vis-à-vis the precariousness of experience. Our experience is essentially precarious because we live "in a world which is not finished and which has not consistently made up its mind where it is going and what it is going to do" (Dewey 1988a: 67). Experience continuously threatens us with new challenges (like the unforeseen Covid pandemic), and Dewey wisely realizes that it is compensatory arrogance to think that we can master this unfathomable flux with fixed metaphysical categories or conceptual, linguistic capacities. Recognition of our vulnerability as mortal, sentient flesh is one reason why I could never accept the limits of Rorty's textualism. His textualism (with its poetics of self-creation) strikes me as a compensatory escape into the reassuring comfort of sentences whose syntactic and semantic rules we know and master, and whose beautiful textual compositions do not suffer as we do from injury, disease, and death. These forms of suffering we experience most clearly through our bodies, which is why philosophy always sought an existence for the soul beyond our somatic mortality, as well as a certainty of truth beyond our fallible knowledge. My insistence that philosophy should take the body and its nondiscursive experience seriously (and thereby address our human limits and weakness, even if we also try to improve our somatic conditions) could be one reason for Rorty's vehement criticism of somaesthetics (Rorty 2001). Somaesthetics is a threat to Rorty's compensatory textual retreat (from the often-brutal meaninglessness and disappointments of experience) into the immortal life of literature, an attractive substitute for religion's promise of immortality. Because I advocate philosophy as an embodied art of living that involves a melioristic dimension of reshaping the self (as you rightly noted in your opening remarks, one might call my position a poetic pragmatism that differs from Rorty's pragmatism of "the strong poet" (Rorty 1989). To sum up, my position regarding experience is obviously closer to Dewey than to Rorty, though I have found traces of the myth of the given in Dewey's claim - evident in his "Qualitative Thought" (Dewey 1984) and his Logic: The Theory of Inquiry (Dewey 1986) - that a unifying felt quality is necessary to all thinking. I shy away from using experience as an epistemological foundation necessary for the truth, meaning, and coherence of every possible thought, but recognize experience as a useful orientation or direction for aesthetic and practical enhancement in personal, social, and environmental contexts. I will not try to explain or defend my nuanced position here - you can find it in Practicing Philosophy (Shusterman 1997) and Thinking through the Body (Shusterman 2012b). Instead, I refer readers to an excellent article by Mathias Girel (Girel 2015) that arbitrates this issue between Dewey, Rorty, Brandom, and myself. I should also note an article where I elucidate the concept of "transactional experiential inquiry" 
as a key methodological orientation in my research that relates to the logic of discovery (Shusterman 2015).

米

Roberta DREON - Your transition from a pragmatist aesthetics to somaesthetics occurred through your book Practicing Philosophy (Shusterman 1997). It coincides with the claim that we should recover the ancient idea of philosophy as a concrete way of life beyond or next to philosophy as a primarily theoretical enterprise, concerning the development of a general form of knowledge and/or criticism about the world and its different aspects. It is clear that your somaesthetics - conceived of as "the critical study of one's own body and the art of cultivating it for improving its experience and use" (Shusterman 2019a: 216) - is a way of practicing philosophy and not only an intellectual proposal. In this view, one might see and attempt to recover the melioristic idea of philosophy pursued by Thoreau and the Pragmatists: a theory should be assumed or dismissed because of the consequences it can have on one's practical life (James 1978) and possibly because of its capacity to improve individual and shared life (Dewey 1988a). However, as you will recall, this is not an exclusively pragmatist point: it can already be found in ancient thought, among Greek and Latin philosophers as well as in Confucius, who has increasingly become a source for your proposal. So what is the main pragmatist heritage in somaesthetics, beyond the idea (now relatively widespread) that the self is fully embodied?

Richard SHUSTERMAN - Please excuse me for making two points of precision that may seem trivial but I consider important. First, it would be wrong to understand the move to somaesthetics as a departure from pragmatist aesthetics. It is rather an extension of pragmatist aesthetics, the fulfilment of a project that was already indicated in the final pages of the first edition of Pragmatist Aesthetics in 1992, which argue for our needing an aesthetic of "bodily practices" that "aesthetically enrich our lives in terms of an enhanced quality and awareness of felt experience" (Shusterman 1992: 261). Second, Practicing Philosophy is only the first (English) publication where I noted the transition; it is not where the transition occurred. The transition occurred through my experience of practicing certain somatic disciplines and my reflection on the experience of those disciplines and on the theories that guided them. The experience of real practice is essential to the way I understand pragmatist aesthetics and somaesthetics. It is not surprising therefore that people can understand my work better when they are better acquainted with its roots in practice. This is one reason why I give practical workshops in somaesthetics. Unfortunately, the institutions who invite me for such workshops have never been philosophy departments, but instead departments in the arts, design, technology, or health studies. Those other departments have much larger budgets to fund such workshops, so I am reluctant to conclude that philosophers would not like those practical workshops.

Now to go deeper into your question. You are right that I certainly know the idea of philosophy as an embodied way of life is very ancient, existing long before both pragmatism and somaesthetics. That was why I explicitly introduced somaesthetics (adopting James's description of pragmatism) as "a new name for certain old ways of thinking" (Shusterman 2000: 263). I don't believe there needs to be what you call an "exclusively pragmatist point" in somaesthetics; in fact, to seek or demand such exclusivity would be to court the sectarianism that I think is foreign to the pluralist, boundary-challenging spirit of the pragmatist thinking I most admire. Nonetheless, pragmatism has certainly shaped the field of somaesthetics in important ways. The 
main pragmatist heritage in somaesthetics (besides the affirmation of embodiment that is very powerful in James and Dewey) derives from two key pragmatist ideas that, again, are not exclusive to pragmatism but extremely central to it. The first you already mentioned - meliorism. I defined somaesthetics "as the critical, meliorative study of the experience and use of one's body as a locus of sensory-aesthetic appreciation (aisthesis) and creative self-fashioning. It is therefore also devoted to the knowledge, discourses, practices, and bodily disciplines that structure such somatic care or can improve it" (Shusterman 2000: 267).

The second key pragmatist idea that is crucial to somaesthetics is the importance of practice and the essential integration of theory and practice. Already when I first outlined the three branches of somaesthetics, two of those branches focused on practice. One was pragmatic somaesthetics - which involves the proposal and critique of various practical methods or disciplines to improve somatic experience (including critique of the values and beliefs presupposed by those methods) - and the other was practical somaesthetics, which is the actual, physical practicing of such somatic methods or disciplines. As I mentioned earlier, this dimension of actual practice is extremely important to my conception of somaesthetics. As a matter of personal fact, I could not have written my books on somaesthetics without the practical experience and professional training I had as a somatic therapist. Nor could I have written what I did about photography and performance without the practical experience of working in performance art with an expert photographic artist, Yann Toma. The papers I have published on somaesthetics and interactive design (coauthored with experts in human-computer interactive technology) all developed from practical workshops with their design groups (Lee 2014; Eriksson et al. 2020). This organic extension of philosophical theory into practical, interdisciplinary collaboration rather than confining one's philosophical work to purely philosophical projects is something that I admire in the pragmatist tradition, though again, it is not exclusive to pragmatism.

\begin{abstract}
***
Roberta DREON - A further searing issue concerns the political implications of somaesthetics. The problem has been already posed to you and you have already given some answers on this topic, but it deserves further discussion, given the importance of the issue at stake. Very succinctly, the objection is that somaesthetics as cultivation of one's own body consciousness and possibilities is individualistic, and that it could ultimately be interpreted as an escape into the private sphere and as involving, if only unwittingly, a confirmation and a reinforcement of neo-liberal politics and economics. Your answer is based on a couple of characteristically pragmatist points: on the one hand, the idea that one's own self and identity is socially configured and, on the other, the belief that democracy is not merely a rational, deliberative, and normative affair. Rather, it concerns a fully embodied community, as we too have emphasized in this journal (see EJPAP 2/2020). By further developing this background, you have drawn an argument from both Confucius and Plato regarding individual action in politics: good governance of the community requires good governance of one's own self as a prerequisite - "the macro-field of political government is essentially based on the micro-field of self-government" (Shusterman 2019a: 218). Incidentally, we could also mention one of the founding text of the Western tradition in aesthetics, namely the Letters on the Aesthetic Education of Man, where Schiller claims that, in order to build a new, more democratic and balanced form of government, humans should pursue a mutual regulation of rational impulses and sensual drives through an
\end{abstract}


education to beauty as "living form." However, I am not fully persuaded by your argument for a series of reasons: there is a tension, I believe, between your emphasizing that coherently with Dewey and Mead - the self is shaped through its social transactions, and your assuming with Confucius and Plato that the cultivation of one's own self and body is the premise for managing community life. Where does this cultivation occur if not within the complex network of already social relationships? Furthermore, in what existential conditions - including social, economic, political, and symbolic factors - can the cultivation of one's own embodied self take place? Probably, only within economically and/ or intellectually privileged situations. If this is true, somaesthetics would unwittingly reinforce a form of elitism, which is far from pragmatism.

Richard SHUSTERMAN - I share your appreciation of Schiller's Letters on the Aesthetic Education of Man. The sixth chapter of Pragmatist Aesthetics involves a close reading of that work in conjunction with T.S. Eliot's "Portrait of a Lady." I have already dealt at length with the stale objections that any concern for the body involves a retreat from the social, a flight into private egotism. Our soma, as the locus of our presence in the world, is where we typically interact in the social sphere; our bodies are very often more public than our minds and thoughts. Because the soma is a transactional entity that exists and thrives only through engagement with its physical and social environment, somaesthetic perception and cultivation (when properly pursued) always involve the perception of its environment, and a consequent concern for it. You cannot feel your body alone; you always feel it with what it stands, sits, or lies on; with the force of gravity or layer of clothes that cover it; or with the surrounding air that cools it or enters its lungs.

As for the polemics about the relationship between self-government and sociopolitical government, you seem to misunderstand me. More importantly, I think your remarks about Confucius and Plato are misleading. We should characterize neither of these great thinkers as advocating that personal individualism is more basic or more important than society. I too am remote from the methodological individualism that denies society's essential, formative role in molding the habits, thoughts, and values of individuals. As you recognize, I take the holist view that individuals are fundamentally shaped by social relations, even in apparently personal or private areas such as taste. (This concern for the social was the reason for my work with Bourdieu, who offered a more contemporary and empirically detailed account of social relations than I found in Dewey.)

Appreciating methodological holism and its insistence on the social construction of individuals does not however negate the importance of also focusing on the individual and her body-governance for achieving better government of society at large. The calamity of the Covid-19 pandemic has highlighted the crucial importance of individual responsibility for bodily care as necessary for the good of society as a whole. Governments can legislate orders for wearing masks, washing hands, selfquarantine, social distancing, etc. But these orders are useless if individuals do not embrace that bodily behavior as self-government. Moreover, what is key to the Chinese conception is that such self-government should begin with the leaders. They need to set the example for other individuals to follow in the self-government of harmonious and ethically attractive behavior. We have seen, all too often during the Covid pandemic, how leaders by not governing themselves in mask wearing, confinement, and social distancing have undermined the public's faith and cooperation, and have thus rendered general governmental policies far more 
ineffective. Since your question may create a misperception of Confucianism, and since the article of mine from which you cite is in French (which may be an obstacle to most readers of our interview), please allow me to cite from that article's English version of the Confucian conception of the self and of the idea of somaesthetic cultivation that emerges from it.

Confucianism insists rather that the individual self is essentially socially constructed. The particular self is defined by the various social relations that shape it. One is the son of $M$ and $F$, the student of $X$, the classmate of $Y$, the teacher of $Z$, the father of $\mathrm{A}$ and $\mathrm{B}$, the husband of $\mathrm{W}$, and so on. These social roles orient one's self-cultivation and determine the direction of one's self-realization. Selfcultivation is always socially situated, and somatic self-cultivation is significantly shaped by one's social roles and duties. Consider, for example, an argument that Mencius brings for somatic self-care and self-cultivation. Recognizing the primacy of one's duty to one's parents, Mencius maintains that satisfying that duty requires fulfilling a prior trust to one's own body or self. "I have heard of those who, having kept their bodies inviolate, could serve their parents, but not of those who failing to do so, still served their parents. Whichever duty I fail to perform, it must not be my duty to my parents, for that is the duty from which all others spring. Whichever trust I fail to fulfill, it must not be that of keeping my body inviolate, for that is the trust from which others arise." In other words, duties to the self are logically implicated in our duties to others, just as our relations to others essentially define the self. (Shusterman 2019a: 218-9)

of course, it is true that people with more leisure and money can afford to take more time for somatic self-cultivation. However, this holds for all sorts of projects of improvement. It is not an argument against somaesthetics per se; in fact, the argument has more power against cultivation in the arts and sciences, literature and philosophy - fields that require special conditions of access to materials and high levels of education. Not everyone can afford to live in New York or Paris and visit the museums and art festivals there, or can afford to purchase tickets to the Opera, or have the time, energy, and literary competence to cultivate oneself with Proust, Joyce, or even Thomas Mann. But everybody has a soma with the ability to breathe and thus to cultivate one's breathing. Most of us can walk and thus can learn to notice how we walk and how we could improve the satisfaction we can get from walking by monitoring and adjusting its particular forms and rhythms, its ways of engaging our limbs, head, torso, and pelvis, as well as our feet. This may all sound like mystical malarkey to theorists for whom somatic thinking is a contradiction in terms. I know that it sometimes takes more than verbal arguments like this one to bring skeptics to appreciate the somaesthetic point of view. Sometimes it takes the experience of a practical workshop to produce the change of perspective.

\footnotetext{
米

Roberta DREON - In a recent paper, entitled "The Invention of Pragmatist Aesthetic," you claim that "the notion of pragmatist aesthetics (though undeniably inspired by Dewey) is essentially the product of neopragmatist thought, and that the term gained wide, international currency only after it began to be employed and promoted systematically through the publication of my book, Pragmatist Aesthetics (1992)." Although it is maybe true that you have coined the term, it seems that the variety of uses of the pragmatist heritage in aesthetics is much broader and more multifaceted, as it also appears from this issue of our journal. Environmental aesthetics, everyday aesthetics, the American tradition of social aesthetics, the conception of aesthetics as philosophy of culture - all of these trends seem
} 
to share important connections with Dewey's view of experience and the uses of artistic practices within human life. Does not your above-mentioned view run the risk of simplifying the picture and of failing to adopt a more pluralistic view that could better match the pragmatist attitude?

Richard SHUSTERMAN - The first thing I should say in response is that the article you mention is not recent. It was written for a 2012 conference that formed part of a nationally funded Polish project on the history, value, and future prospects of pragmatist aesthetics, a conference scheduled to coincide with the twentieth anniversary of my 1992 book with that name (whose Polish translation appeared in 1998). In that historical, bio-bibliographical context, my article sought to treat the following questions. What neopragmatist influences led me from analytic philosophy to pragmatist aesthetics; how I found the essential roots of pragmatist aesthetics in classical pragmatism; and why despite the fact the Dewey rejected the notion of a specific pragmatist aesthetics, my book took that name and how the name became popular and came to define Dewey's aesthetics, as it were, malgré lui? It is simply a fact (embarrassing or not) that what first brought me to pragmatism was not Dewey's aesthetics but Rorty's hermeneutics (despite my disagreements with him). My first pragmatist writings are on interpretation and evaluation (Shusterman, 1988a; 1988b). It is also a fact, (frankly confessed in that article) that my book's title "Pragmatist Aesthetics" was not my own invention. The title was decided by my editor at Blackwell, who published my earlier (edited) book, Analytic Aesthetics and insisted that "Pragmatist Aesthetics" would be a good title for an aesthetic sequel, far better than the vaguely evocative title ("Living Beauty, Rethinking Art") that I proposed and that got relegated to the subtitle. My editor was right; the term "pragmatist aesthetics" proved fruitful and multiplied (to borrow the idiom of Genesis), serving a variety of enlightening theories and applications, not only in philosophy but also in several other disciplines concerned with aesthetics. I have always welcomed such pluralism and diversity in pragmatist aesthetics, and have repeatedly advocated it by pointing to its presence in Emerson, William James, and Alain Locke, as well as in Rorty, Margolis, Goodman, and others. In the very article you cite, I insist that pragmatist aesthetic cannot be reduced to a single theory or captured in a single article "as many authors have contributed to its development in a variety of disciplines, including the field of somaesthetics that emerged from it" (Shusterman 2014: 26). As one of the themes of that 2014 article was the pragmatic power of names, so one of the article's methods of research involved quantifying (till the year 2012) the usage of that name "pragmatist aesthetics" in philosophy and humanities journals and other research publications available in digital data bases. The study also included (for comparison and contrast) the amounts of usage of related names like "pragmatic aesthetics," "pragmatist esthetics," "aesthetics of pragmatism" and then it compared such usage before and after the publication of Pragmatist Aesthetics. Having recently examined the data since 2012, I am happy to report that the term "pragmatist aesthetics" has continued to increase in popularity thanks to the fine work of the many scholars in this field. I hope that Dewey would not regret that his aesthetic masterwork is now identified with a concept he rejected. 
Roberta DREON - Let us conclude this interview with a reference to your latest research project, namely the philosophical account of human sexuality that you are developing. Once more, you have confirmed your courage in putting an unusual, thorny issue at the center of philosophical debate. We can easily imagine how this latest interest of yours is related to somaesthetics, but what, if any, are its connections with the pragmatist approach in aesthetics?

Richard SHUSTERMAN - Thanks for this question and for the interview in general. Cambridge University Press has scheduled, for March 2021, the publication of my Ars Erotica: Sex and Somaesthetics in the Classical Arts of Love. This book does not propose a systematic philosophical account of sexuality but rather provides historical, cultural, and philosophical materials that I hope offer important insights for a better understanding of the rich potential of meaning and beauty in sexual desire and erotic love. I wish I shared your confidence that the issues of eroticism and sexuality will be at the center of philosophical debate. There are powerful reasons to fear that contemporary theorists will largely ignore or reject these issues and my book. Many today will view the erotic as politically incorrect because inextricably poisoned by traditions of predatory patriarchy; others would follow an earlier line of your questioning and reject the whole topic of eroticism as essentially privatist and elitist because of its central somatic concerns. Who can afford to think about improving one's lovemaking to make it richer and more satisfying in terms of aesthetic and ethical values? Only a privileged minority of the world's population, critics will say. Even if this contestable claim is true, does it constitute a good enough reason to exclude the topic from philosophical consideration and ignore improving the lives of that (still numerous) minority? Moreover, could not greater recognition of the aesthetic and ethical values of erotic love help foster progressive thinking to make more of these values possible for more people? Even in dark times, we can contemplate improving the values of shared communicative sensuous pleasure as building blocks for improved social understanding. Could not the beauty of love provide a microphysics of pleasurable solidarity and emancipatory "somapower" to help inspire utopian social reform (Shusterman 2019b; Koczanowicz 2020)? Love, including erotic love, still has, I believe, its inspirational powers. I know this idea sounds unrealistically utopian and romantic, but as melioristic hope is central to the pragmatist tradition, I don't believe that utopian or romantic pragmatism is a selfcontradictory position. For that reason, some French theorists have critically characterized my philosophy as juvénile, while Germans sometimes disparage it as kindisch. I am not frightened or ashamed of those labels.

There is another reason why many philosophers will ignore the contents of my book. Its contents do not constitute a familiar topos for contemporary philosophy, despite Foucault's important work on the history of sexuality. We have no philosophy journals devoted to eroticism; there is no Review of Erosophy to do what The Review of Metaphysics does for questions of ontology. For such reasons (as well as others), I often thought of abandoning my project on erotic love; it required far more research than I initially imagined because I did not want it to be Eurocentric and ahistorical. The book deals with seven richly complex and prominent premodern cultures that have significantly shaped our present. That research taught me how ignorant I was, and how much I still have to learn.

As for your question about the book's relation to the pragmatist tradition, I can answer most frankly by defining this relation as essential, but essentially negative. It 
is essential in the following sense. An embodied, meliorist philosophy like pragmatism (and especially a philosophy with an aesthetics celebrating experiences of consummatory fulfilment) should regard the sexual soma with its needs, drives, and joys of sexual satisfaction as an essential site for improving embodied experience. This meliorative cultivation includes improving the ways that diverse forms of erotic engagement and fulfilment can form an aesthetically and ethically uplifting communicative experience while enhancing rather than damaging social harmony. Sex is an essential part of life that pragmatism, with its embodied Darwinian heritage, should not neglect. However (and here is the negative element), the pragmatist tradition does neglect it, perhaps because of the lingering prudishness of American puritan culture, or at least of American academic culture. This discomfort with the sexual may explain Dewey's disregard for Freud. But at least Dewey recognized the philosophical and moral legitimacy of writing about sexual ethics, when he nobly defended the realm of academic freedom and the reputation of Bertrand Russell, who had been banned from teaching at New York's City College (in 1940) because of his writings on topics relating to sex (Dewey 1988b).

Discomfort with philosophizing the sexual might also have contributed to Rorty's anti-somatic attitude. In criticizing somaesthetics, he notes, for example, how "Foucault's, Bataille's, and Deleuze's discussions of the body leave [him] cold" (Rorty 2001: 156); and these authors are well known for their views on sexuality and desire. In any case, my resolve to research eroticism crystalized when I saw that William James (the pragmatist personality for whom I have the most affection) went so far as to invoke what he calls our "antisexual instinct," describing it as "the actual repulsiveness to us of the idea of intimate contact with most of the persons we meet, especially those of our own sex" (James 1981: 1053-4). I then decided the pragmatist tradition could use a volunteer to address its neglect of eroticism and sexuality. That decision reflects my pragmatist desire to do useful philosophical work. One way to be useful is to work on topics that are largely neglected in academic philosophy but that seem important to the problems of individuals and societies, and that therefore should have some philosophical significance and merit philosophical attention.

1 This concern for topics that seemed largely neglected by academic philosophy explains my 1990s work on rap and country music, my early research on somaesthetics and body consciousness, and more recently my theorizing of forms of eating and fashion (Shusterman 2016b, 2017). If these topics are now receiving more attention, the field of ars erotica continues to suffer philosophical neglect. I know that many philosophers regard these topics as frivolous and outside the bounds of philosophy. But the democratic, pluralistic, and embodied spirit of pragmatism provides me some support. The interdisciplinary nature of this work (Koczanowiz \& Małecki 2012) can also take inspiration from the pragmatist tradition (whose exemplars were often more than mere philosophers: semioticians, psychologists, educators, political theorists, sociologists, and literary critics). I am grateful to find the spirit of pragmatist openmindedness continued in this Journal, which has allowed me, once again, to explain my varieties of pragmatist aesthetics (EJPAP 4:1/2012). 


\section{BIBLIOGRAPHY}

COMETTI Jean-Pierre, (2010), Qu'est-ce que le pragmatisme?, Paris, Gallimard.

DEWEY John, (1980), “The Need for a Recovery of Philosophy," in The Middle Works, 1899-1924, Volume 10: 1916-1917, Carbondale and Edwardsville, Southern Illinois University Press, 3-48. DEWEY John, (1984), “Qualitative Thought,” in The Later Works, 1925-1953, Volume 5, 1929-30. DEWEY John, (1986), Logic: The Theory of Inquiry, in The Later Works, 1925-1953, Volume 12: 1938, Carbondale and Edwardsville, Southern Illinois University Press.

DEWEY John, (1988a), Experience and Nature, in The Later Works, 1925-1953, Volume 1, 1929,

Carbondale and Edwardsville, Southern Illinois University Press.

DEWEY John, (1988b), “The Case for Bertrand Russell,” in The Later Works, 1925-1953, Volume 14, 1939-1941, 231-5.

DEWEY John, (1989), Art as Experience, in The Later Works, 1925-1953, Volume 10, 1934, Carbondale and Edwardsville, Southern Illinois University Press.

DEWEY John, (2005/2010), L'Art comme experience, Paris, Gallimard.

ERIKSSON Sara, HÖÖK Kristina, SHUSTERMAN Richard et al., (2020), "Ethics in Movement: Shaping and Being Shaped in Human-Drone Interaction," Proceedings of CHI 2020, paper 549, 1-14. Online: (https://dl.acm.org/doi/abs/10.1145/3313831.3376678).

EUROPEAN JOURNAL OF PRAGMATISM AND AMERICAN PHILOSOPHY, (2012), “A Symposium on R. Shusterman, Pragmatist Aesthetics 20 years later" (with contributions by Paolo D'Angelo, Roberta Dreon, Heidi Salaverria, and Krystyna Wilkoszewska, and a response by Richard Shusterman), EJPAP, 4 (1). Online: (https://journals.openedition.org/ejpap/758).

JAMES William, (1976), Essays in Radical Empiricism, Cambridge and London, Harvard University Press.

JAMES William, (1978), Pragmatism and the Meaning of Truth, Cambridge and London, Harvard University Press.

JAMES William, (1981), The Principles of Psychology, Cambridge and London, Harvard University Press.

GIREL Mathias, (2015), "Perfectionism in Practice: Shusterman's place in Recent Pragmatism," Contemporary Pragmatism, 12 (1), 156-79.

KOCZANOWICZ Leszek, (2020), “Toward a democratic Utopia of everydayness: microphysics of emancipation and somapower," History of European Ideas, 46 (8), 1122-33.

KOCZANOWICZ Dorota \& Wojciech MALECKI (eds), (2012), Shusterman's Pragmatism: Between Literature and Somaesthetics, Amsterdam and New York, Rodopi.

LEE Wonjun, LIM Youn-kyung \& Richard SHUSTERMAN, (2014), "Practicing somaesthetics: exploring its impact on interactive product design ideation," Proceedings of the 2014 conference on Designing interactive systems, 1055-64. Online: (https://dl.acm.org/doi/pdf/ 10.1145/2598510.2598561).

RORTY Richard, (1989), Contingency, Irony, and Solidarity, Cambridge and New York, Cambridge University Press. 
RORTY Richard, (2001), "Response to Richard Shusterman," in M. Festenstein \& S. Thompson (eds), Richard Rorty: Critical Dialogues, Cambridge, Polity Press, 153-7.

SHUSTERMAN Richard, (1988a), “Croce on Interpretation: Deconstruction and Pragmatism," New Literary History, 20 (1), 199-216.

SHUSTERMAN Richard, (1988b), T.S. Eliot and the Philosophy of Criticism, New York and London, Columbia University Press.

SHUSTERMAN Richard, (1992), Pragmatist Aesthetics: Living Beauty, Rethinking Art, Oxford, Blackwell. SHUSTERMAN Richard, (1992/2018), L'Art à l'état vif: La pensée pragmatiste et l'esthétique populaire, Paris, Éditions de Minuit/Éditions de l'Éclat.

SHUSTERMAn Richard, (1997), Practicing Philosophy: Pragmatism and the Philosophical Life, New York, Routledge.

SHUSTERMAN Richard, (2000), Pragmatist Aesthetics: Living Beauty, Rethinking Art, 2nd edition, Lanham-Boulder-New York-Oxford, Rowman \& Littlefield.

SHUSTERMAN Richard, (2002), Surface and Depth: Dialectics of Criticism and Culture, Ithaca and London, Cornell University Press.

SHUSTERMAN Richard, (2005/2010), “Présentation de l'édition française," in John Dewey, L'Art comme experience, Paris, Gallimard.

SHUSTERMAn Richard, (2008), Body Consciousness. A Philosophy of Mindfulness and Somaesthetics, Cambridge, Cambridge University Press.

SHUSTERMAn Richard, (2012a), Aesthetic Transactions: Pragmatist Philosophy through Art and Life, Paris, Galerie Michel Journiac. Online: (https://aesthetictransactions.webs.com/).

SHUSTERMAN Richard, (2012b), Thinking through the Body: Essays in Somaesthetics, Cambridge, Cambridge University Press.

SHUSTERMAN Richard, (2014), "The Invention of Pragmatist Aesthetics: Genealogical Reflections on a Notion and a Name," in Małecki Wojciech (ed.), Practicing Pragmatist Aesthetics. Critical Perspectives on the Arts, Leiden, Brill, 11-32.

SHUSTERMAN Richard, (2015), “Transactional Experiential Inquiry: From Pragmatism to Somaesthetics," Contemporary Pragmatism, 12 (1), 180-95.

SHUSTERMAN Richard, (2016a), The Adventures of the Man in Gold/Les Aventures de l'Homme en Or, (with images by Yann Toma), Paris, Hermann.

SHUSTERMAN Richard, (2016b), "Somaesthetics and the Fine Art of Eating," in Sherri Irvin (ed.), Body Aesthetics, Oxford, Oxford University Press, 261-80.

SHUSTERMAN Richard, (2017), "Fits of Fashion: The Somaesthetics of Style," in Stefano Marino \& Giovanni Matteucci (eds), Philosophical Perspectives on Fashion, London, Bloomsbury, 91-106.

SHUSTERMAN Richard, (2019a), "Somaesthétique et politique. Incorporer une esthétique pragmatiste à l'action sociale," Pragmata, 2, 214-40. Online: (https:// revuepragmata.files.wordpress.com/2020/01/pragmata-2019-2-shusterman.pdf) SHUSTERMAN Richard, (2019b), "Bodies in the Streets: The Soma, the City, and the Art of Living," in Id. (ed.), Bodies in the Streets: The Somaesthetics of City Life, Leiden, Brill, 13-37. 


\section{AUTHORS}

\section{RICHARD SHUSTERMAN}

Florida Atlantic University

shuster1[at]fau.edu

\section{ROBERTA DREON}

Ca' Foscari University, Venice

robdre[at]unive.it 